\title{
Glosa aprobująca do postanowienia Sądu Apelacyjnego w Katowicach z dnia 20 lutego 2014 r., III AUz 28/14
}

Teza: Brak określenia wartości przedmiotu zaskarżenia nie uniemożliwia nadania biegu sprawie w zakresie postępowania apelacyjnego. Zarówno bowiem opłata, jak i koszty zastępstwa procesowego w sprawach z zakresu ubezpieczeń społecznych nie są uzależnione od wartości przedmiotu sporu, która może być istotna dopiero przy stwierdzaniu dopuszczalności skargi kasacyjnej.

\section{1.}

W glosowanym orzeczeniu podniesiono zagadnienie ważne z punktu widzenia postępowania apelacyjnego w sprawach sądowych z zakresu ubezpieczeń społecznych, mianowicie skutków procesowych nieoznaczenia przez apelującego wartości przedmiotu zaskarżenia. W orzecznictwie można bowiem dostrzec w tej materii dwa odmienne stanowiska. Według pierwszego, formalistycznego, sąd powinien bezwzględnie odrzucić taki 
środek zaskarżenia, jeżeli ww. brak nie został usunięty w terminie (art. 370 k.p.c.). Według drugiego, które można określić jako liberalne, dopuszczalne jest przyjęcie do rozpatrzenia apelacji, w której nie określono wartości przedmiotu zaskarżenia, jeżeli brak ten nie ma żadnego wpływu na wysokość opłaty sądowej.

\section{2.}

Przykładem formalistycznej oceny braku określenia wartości przedmiotu zaskarżenia jest stanowisko Sądu Apelacyjnego w Krakowie, wyrażone w postanowieniu z dnia 25 września 2012 r., III AUz 166/12 (LEX nr 1220521). Zdaniem Sądu „bezpodstawne jest twierdzenie, że dla ustalenia obowiązku podania wartości przedmiotu zaskarżenia jako jednego z elementów apelacji, należy odwołać się do treści art. $126^{1} \S 1$ k.p.c.”. Sąd ten, powołując się na uchwałę Sądu Najwyższego z dnia 7 lipca 2005 r., II UZP 7/05 (LEX nr 152347), uznał, że art. 126¹ §1 k.p.c. „określając wymogi formalne pism procesowych, precyzuje, że podanie wartości przedmiotu sporu lub wartości przedmiotu zaskarżenia konieczne jest, jeżeli od tej wartości zależy właściwość rzeczowa sądu, wysokość opłaty lub dopuszczalność środka odwoławczego, zaś oznaczenie w apelacji wartości przedmiotu zaskarżenia funkcji tych już nie spełnia”. Jako podstawowy argument mający przemawiać za zasadnością ww. stanowiska wskazuje się, że wymóg oznaczania wartości przedmiotu sporu i wartości przedmiotu zaskarżenia ma na celu ustabilizowanie przedmiotu sporu i zakresu zaskarżenia dla eliminacji możliwości dowolnego ich określania w poszczególnych stadiach procesu dla potrzeb dopuszczalności zaskarżenia oraz ponoszenia kosztów procesu (ich rozliczenia między stronami), na co zwracał uwagę Sąd Najwyższy w uchwale z dnia 29 lipca 2003 r., III PZP 10/03 (LEX nr 79124).

3.

Rozstrzygnięciem stojącym a contrario w stosunku do ww. stanowiska jest glosowane postanowienie Sądu Apelacyjnego w Katowicach. Zdaniem 
sądu w przedmiocie braków apelacji w postaci nieoznaczenia wartości przedmiotu zaskarżenia powinna być stosowana racjonalna i nieprzesadnie ścisła ocena spełnienia przez pisma procesowe przewidzianych dla nich wymagań formalnych, co oznacza, iż „odrzucenie apelacji z tego powodu jest możliwe jedynie wówczas, gdy od oznaczenia wartości przedmiotu zaskarżenia zależy możliwość nadania apelacji właściwego biegu”. W innym wypadku obowiązek jej podania - mający faktycznie służebny charakter wobec innych regulacji procesowych - stałby się obowiązkiem samodzielnym. Zdaniem sądu „nie jest on tymczasem na tyle poważny i niezbędny, by z powodu jego niewskazania ad casum odrzucać apelację”. Taka praktyka godzi bowiem w istotę prawa do sądu, którego podstawową rolę stanowi rozpoznanie merytoryczne żądania strony, a nie poszukiwanie formalnych wybiegów dla uchylenia się od tego obowiązku (por. postanowienia Sądu Najwyższego z dnia 11 grudnia 2009 r., II UZ 43/09, LEX nr 583825 oraz z dnia 11 września 2011 r., II PZ 22/11, LEX nr 1108549). Tym samym, zdaniem sądu, brak określenia wartości przedmiotu zaskarżenia nie uniemożliwia nadania biegu sprawie w zakresie postępowania apelacyjnego, zarówno bowiem opłata, jak i koszty zastępstwa procesowego w sprawach z zakresu ubezpieczeń społecznych nie są uzależnione od wartości przedmiotu sporu, która może być istotna dopiero przy stwierdzaniu dopuszczalności skargi kasacyjnej.

\section{4.}

W dyskusji na temat skutków procesowych, jakie powinien nieść ze sobą brak wskazania wartości przedmiotu zaskarżenia w sprawach z zakresu ubezpieczeń społecznych, należy w pełni przychylić się do stanowiska Sądu Apelacyjnego w Katowicach, wyrażonego w glosowanym orzeczeniu.

Pamiętać należy, że postępowania z zakresu ubezpieczeń społecznych nie dotyczą li tylko kwestii odmowy przyznania świadczeń pieniężnych w ściśle określonej wysokości. W praktyce może bowiem wystąpić dość istotny problem sprowadzający się do sposobu wyliczenia wartości przedmiotu zaskarżenia, gdy postępowanie dotyczy ustalenia istnienia obowiązku odprowadzenia składek na ubezpieczenia społeczne. Nie zawsze moż- 
na posiłkować się w tym względzie orzecznictwem Sądu Najwyższego, w którym przyjmuje się, iż „wartość przedmiotu zaskarżenia w sprawie o wysokość podstawy wymiaru składek na ubezpieczenia społeczne i ubezpieczenie zdrowotne równa jest różnicy pomiędzy wysokością składki zapłaconą przez odwołującego się i składką należną, ustaloną w decyzji za sporny okres”. Stwierdzenie to odnosi się bowiem do sytuacji, gdy sama podstawa wymiaru składek nie jest sporna lub spór toczy się o wysokość składek (por. postanowienie Sądu Najwyższego z dnia 27 lutego 2014 r., II UZ 83/13), stąd też nie będzie można go uwzględnić, gdy spór sądowy toczy się o ustalenie podstawy wymiaru składki i wskazanie podmiotu zobowiązanego do jej odprowadzenia.

Sytuacja powyższa może okazać się jeszcze bardziej skomplikowana, gdy wysokości składki zaległej nie określono w zaskarżonej przez stronę decyzji. Problem taki pojawia się na ogół w sytuacji, w której organ rentowy w jednej i tej samej decyzji wskazuje podmiot zobowiązany do uiszczenia zaległych jego zdaniem składek na ubezpieczenia społeczne oraz określa (zsumowaną) podstawę wymiaru składek bez uzasadnienia metodyki obliczeń i dokumentacji (niejednokrotnie dla strony niedostępnej), na podstawie której ustalenia te poczynił. Pamiętać należy, że zgodnie z art. 368 § 2 zd. 2 k.p.c. wartość przedmiot zaskarżenia może być oznaczona na kwotę wyższą od wartości przedmiotu sporu wskazanej w pozwie jedynie wtedy, gdy powód rozszerzył powództwo lub sąd orzekł ponad żądanie. Tymczasem wartości przedmiotu sporu nie określa się w odwołaniu od decyzji, de facto zastępującym w postępowaniu z zakresu ubezpieczeń społecznych pozew. Wymogi formalne stawiane odwołaniu od decyzji organu rentowego określa art. $477^{10} \S 1$ k.p.c., zgodnie z którym odwołanie powinno zawierać oznaczenie zaskarżonej decyzji, określenie i zwięzłe uzasadnienie zarzutów i wniosków oraz podpis ubezpieczonego albo jego przedstawiciela ustawowego lub pełnomocnika. W orzecznictwie dodaje się natomiast, że „odwołanie od decyzji organu rentowego, jak każde pismo procesowe winno zawierać elementy wskazane w art. 126 § 1 k.p.c., w tym oznaczenie rodzaju pisma, osnowę wniosku oraz dowody na poparcie przytoczonych okoliczności, a także, z uwagi na jego charakter, zawierać oznaczenie zaskarżonej decyzji z przytoczeniem zarzutów wobec niej i uzasadnienie (analogia z art. 368 k.p.c.)” (por. postanowienie Sądu Najwyższego 
z dnia 20 kwietnia 2000 r., II UKN 132/00, LEX nr 161252), zastrzegając jednak, że „odwołanie od decyzji organu rentowego (...) nie podlega rygorom przewidzianym dla pozwu w art. 187 k.p.c.” (por. postanowienie Sądu Najwyższego z dnia 26 września 2005r., II UZ 52/05, LEX nr 189962). Tym samym, przynajmniej teoretycznie, w sytuacji, w której zaskarżone decyzje organu rentowego nie precyzują wysokości zaległych składek na ubezpieczenia społeczne, wartość przedmiotu zaskarżenia można określić jako 0 zł. Działanie takie, choć mało profesjonalne, pozwala uniknąć ewentualnych błędów strony zmuszonej do samodzielnych obliczeń należności składkowych. Oczywistym jest bowiem, że w takiej sytuacji obowiązek ustalenia wartości przedmiotu zaskarżania byłby przerzucony na sąd I instancji weryfikujący braki apelacji, na zasadzie art. art. 368 § 2 k.p.c. w zw. $\mathrm{z}$ art. 25 §1 k.p.c.

W dyskusji prowadzonej w przedmiocie skutków procesowych nieokreślenia w apelacji wartości przedmiotu zaskarżenia wskazać należy również, że liberalne podejście do tego zagadnienia niejako wpisuje się w podnoszony przez judykaturę postulat odformalizowania postępowania w sprawach z zakresu ubezpieczeń społecznych i racjonalizowania treści pism składanych przez strony w oparciu o rzeczywistą wolę w nich wyrażoną (por. wyrok Sądu Apelacyjnego w Lublinie z dnia 19 grudnia 2012 r., III AUa 1005/12, LEX nr 1237286). Jeżeli więc z apelacji i załączonych do niej dokumentów jednoznacznie wynika, że strona uiściła opłatę od apelacji w wymaganej wysokości i skierowała środek zaskarżenia do właściwego rzeczowo i miejscowo sądu w wymaganym terminie, brak określenia wartości przedmiotu zaskarżenia nie powinien tamować postępowania i powodować jej odrzucenia. Okoliczność ta nie powinna stanowić przeszkody do przyjęcia i rozpatrzenia apelacji zwłaszcza wtedy, gdy z treści środka zaskarżenia jednoznacznie wynika, że strona zakwestionowała decyzję organu rentowego i wydany przez sąd I instancji wyrok w całości. 